\title{
First report of Podosphaera pannosa causing powdery mildew on Rosa chinensis in Brazil
}

\author{
Wéverson Lima Fonseca ${ }^{1}$ (D) José Emilson Cardoso ${ }^{2}$ - Cristiano Souza Lima ${ }^{1} \cdot$ Francisco Marto Pinto Viana ${ }^{2}$. \\ Márcio Akio Ootani ${ }^{3} \cdot$ Regimara Francisca Bernardo da Silva Vieira ${ }^{1} \cdot$ Wallysson Nascimento Lima ${ }^{1}$
}

Received: 12 October 2019 / Accepted: 29 January 2020 / Published online: 3 February 2020

(C) Società Italiana di Patologia Vegetale (S.I.Pa.V.) 2020

Keywords Miniature rose $\cdot$ Powdery mildew $\cdot$ ITS

Miniature rose (Rosa chinensis Jacq.) is a shrub-plant belonging to Rosaceae family, originated from Asia and cultivated in Brazil for medicinal and ornamental uses. In August 2016, symptoms and signs of powdery mildew were observed on leaves of miniature rose in Guaramiranga municipality, Ceará State. A specimen (OID99) was collected from symptomatic leaves and examined in the Plant Pathology Laboratory of Embrapa Agroindústria Tropical, Fortaleza, Ceará. In the morphological analysis, the fungus presented epiphytic mycelia and erect, septate, hyaline and unbranched conidiophores. The basal cells were cylindrical, straight and slightly curved at the base. Conidia $(n=50)$ formed chains at the conidiophore apex and were unicellular, hyaline, ellipsoidovoid to doliiform, with fibrosin bodies, measuring 22.7 to $31.9 \mu \mathrm{m}$ long and 12.4 to $19.5 \mu \mathrm{m}$ wide. Appressoria in mycelia were simple and nipple-shaped. Chasmothecia were not observed. The morphological characteristics observed were typical of the asexual stage of Podosphaera sensu Braun and Cook (2012). The genomic DNA was extracted with DNeasy Plant Mini Kit (QIAGEN) from pathogen mycelia collected on the host leaves. The polymerase chain reaction (PCR) amplifications of the internal transcribed spacer (ITS) from the rDNA were conducted with ITS1F / P3R primers (Meeboon and Takamatsu 2015). The PCR product

Wéverson Lima Fonseca

weverson.limaf@gmail.com

1 Departamento de Fitotecnia, Centro de Ciências Agrárias, Universidade Federal do Ceará, Fortaleza, CE CEP 60356-001, Brazil

2 Laboratório de Fitopatologia, Embrapa Agroindústria Tropical, Caixa Postal 3761, Fortaleza, CE CEP 60356-001, Brazil

3 Cetene/Laboratório de Bioprocessos, Universidade Federal de Pernambuco, Recife, PE CEP 50740-540, Brazil was sequenced and the sequence of the ITS region of the pathogen was deposited in GenBank under the accession number MN558951. BLASTn analysis showed $>99 \%$ identity with that of Podosphaera pannosa from Eucalyptus urophylla and Rosa sp. (KX185528 and KX355454) (Fonseca et al. 2017). To the best of our knowledge, this is the first report of $P$. pannosa causing powdery mildew on miniature rose plant in Brazil. Under favorable environmental conditions this disease could threat the rose industry in some producing areas of the country.

Acknowledgements The authors thank the Conselho Nacional de Desenvolvimento Científico e Tecnológico (CNPq) and Coordenação de Aperfeiçoamento de Pessoal de Nível Superior (CAPES) for scholarship support.

\section{Compliance with ethical standards}

This article does not contain any studies with human participants or animals performed by any of the authors.

Conflict of interest The authors declare that have no conflict of interest.

\section{References}

Braun U, Cook RTA (2012) Taxonomic manual of the Erysiphales (powdery mildews). CBS biodiversity series no. 11. CBS, Utrecht, the Netherlands

Fonseca NR, Guimarães LM, Pires RP, Klopfenstein NB, Alfenas AC (2017) Eucalypt powdery mildew caused by Podosphaera pannosa in Brazil. Trop Plant Pathol 42(4):261-272

Meeboon J, Takamatsu S (2015) Erysiphe viburni-plicati and Podosphaera photiniae, two new species of Erysiphales (Ascomycota) from Japan. Mycoscience 56(1):14-23

Publisher's note Springer Nature remains neutral with regard to jurisdictional claims in published maps and institutional affiliations. 